\title{
ВПЛИВ ГОСТРОЇ КРОВОВТРАТИ, УСКЛАДНЕНОЇ ІШЕМІЄЮ- РЕПЕРФУЗІЄЮ КІНЦІВКИ, НА ДИНАМІКУ ПОКАЗНИКІВ ГЛУТАТІОНОВОЇ АНТИПЕРОКСИДАЗНОЇ СИСТЕМИ В СЕЛЕЗІНЦІ ТА ЙОГО КОРЕКЦІЯ КАРБАЦЕТАМОМ
}

Вступ. Порушення глутатіонової антипероксидазної системи є одним із ключових механізмів гострої крововтрати та ішемічно-реперфузійного синдрому. В адаптаційно-компенсаторних процесах при крововтраті важливу роль відіграє селезінка. Однак стан глутатіонової антипероксидазної системи в селезінці вивчено недостатньо. Немає даних про ефективність за цих умов карбацетаму, який проявив виражений протекторний вплив на ензимну ланку антиоксидантного захисту селезінки.

Мета дослідження - з'ясувати динаміку показників глутатіонової антипероксидазної системи в селезінці за умов гострої крововтрати, ускладненої ішемією-реперфузією кінцівки, та оцінити ефективність корекції виявлених порушень карбацетамом.

Методи дослідження. В експериментах використано 108 нелінійних шурів-самців масою 200-220 2. Усі дослідження виконано під тіопентал-натрієвим наркозом. У тварин моделювали ішемію-реперфузію кінцівки, гостру крововтрату і поєднували ці ушкодження. В окремій групі проводили корекцію виявлених порушень карбацетамом. Через 1 і 2 год, а також через 1, 7 та 14 діб у селезінці піддослідних тварин визначали вміст відновленого глутатіону і глутатіонпероксидазну активність.

Результати й обговорення. Моделювання гострої крововтрати, ускладненої ішемією-репероруією кінцівки, в селезінці сприяє найбільшому виснаженню вмісту відновленого глутатіону і глутатіонпероксидазної активності, починаючи з 2 год експерименту. Через 1 добу величина досліджуваних показників досягала мінімального рівня і була статистично вірогідно меншою, ніж за умов моделювання лише гострої крововтрати. Застосування карбацетаму мало протекторний вплив на вміст у селезінці відновленого глутатіону (після 7 діб використання) і глутатіонпероксидазну активність (через 14 діб), що ставить карбацетам у ряд перспективних засобів комплексної терапії порушень, зумовлених гострою крововтратою та ішемічно-реперфузійним синдромом.

Висновки. Моделювання гострої крововтрати, ускладненої ішемією-реперфузією кінцівки, зумовлює зниження вмісту відновленого глутатіону і глутатіонпероксидазної активності в селезінці з максимумом через 1 добу експерименту. Застосування карбацетаму сприяє протекції порушень вмісту відновленого глутатіону в селезінці через 7 діб використання, глутатіонпероксидазної активності - через 14 діб.

КЛЮЧОВІ СЛОВА: гостра крововтрата; ішемія-реперфузія кінцівки; селезінка; відновлений глутатіон; глутатіонпероксидаза; карбацетам.

ВСТУП. Глутатіоновій антипероксидазній системі (ГАПС) відводять вагому роль у регуляції вільнорадикального ушкодження. Відновлений глутатіон (ВГ) як один з головних компонентів ГАПС здатний реагувати з вільними радикалами, інгібувати пероксидне окиснення ліпідів [1]. За механізмом дії його розглядають як донатор протона в системі складних окисно-відновних реакцій як у водній, так і ліпідній фразах біологічних мембран. Глутатіон в організмі бере участь у знешкодженні ксенобіотиків; захищає від активних сполук оксигену; підвищує резистентність клітин до негативного впливу стрес-сракторів; (с) І. В. Яворська, 2021. спричиняє вплив на проліфрерацію клітин та підтримує фрункціональний стан біологічних мембран [2].

У системі захисту клітин від надлишку активних фрорм оксигену функції ВГ найчастіше виконує за допомогою ензимної ланки, представленої спектром глутатіонозалежних ензимів [3, 4].

Глутатіонпероксидаза $є$ одним із ключових ензимів ГАПС, вона каталізує реакцію окиснення глутатіону і, відповідно, дезактивацію пероксиду водню, а також розкладає гідропероксиди ліпідів 3 малим розміром молекул [5]. При зменшенні глутатіонпероксидазної (ГП) активності знижується стійкість організму до окисного ураження, 
що може призводити до розвитку вільнорадикальної патології.

Порушення ГАПС належить до важливих механізмів гострої крововтрати й ішемічно-реперсузійного синдрому [6]. Це тим більш важливо, що гостра крововтрата 3 кінцівок $€$ основною причиною смертності за умов бойової травми і більшість таких поранених госпіталізують $з$ накладеним на кінцівку джгутом [7]. Вважають, що безпечний термін накладання джгута з повною ішемією кінцівки становить 2 год. Однак у роботах ряду авторів показано, що моделювання лише двогодинної ішемії кінцівки здатне викликати посилення ліпідної пероксидації 3 компенсаторним посиленням антиоксидантного захисту, зокрема супероксиддисмутазної і каталазної активності у внутрішніх органах [8]. В аналогічних дослідженнях доведено компенсаторне зростання вмісту ВГ у легенях протягом першої години реперфрузійного періоду [9]. Проте ускладнення ішемією-реперфузією кінцівки гострої крововтрати супроводжується його значним зниженням, що дало підставу вважати вагомою роль ГАПС у патогенезі модельованих уражень.

Відомо, що при крововтраті селезінка відіграє значну роль у реалізації адаптаційно-компенсаторних процесів завдяки виходу крові з депо та стимуляції еритропоезу [10, 11]. Однак стан ГАПС у селезінці після моделювання гострої крововтрати, ускладненої ішемією-репердузією кінцівки, вивчено недостатньо. Немає даних про еорективність за цих умов карбацетаму, що, як показали наші попередні дослідження [12], знижував інтенсивність процесів ліпідної пероксидації в селезінці.

Мета дослідження - з'ясувати динаміку показників глутатіонової антипероксидазної системи в селезінці за умов гострої крововтрати, ускладненої ішемією-реперфузією кінцівки, та оцінити есективність корекції виявлених порушень карбацетамом.

МЕТОДИ ДОСЛІДЖЕННЯ. В експериментах використано 108 нелінійних щурів-самців масою 200-220 г. Усі дослідження виконано 3 дотриманням правил Європейської конвенції про захист хребетних тварин, що використовуються для дослідних та інших наукових цілей (Страсбург, 1984).

Піддослідних тварин поділили на 5 груп: контрольну та 4 дослідних (по 6 щурів у кожній). Усі втручання виконано за умов тіопентал-натрієвого наркозу (40 мг·кг-1 маси тіла). У 1-й дослідній групі тваринам моделювали ішемію-реперфрузію кінцівки шляхом накладання проксимально на ліву лапку джгута впродовж 120 хв. Засто- совували смужку еластичного джгута "SWAT-T" (США) шириною 10 мм. Такий джгут має мінімальний негативний вплив на підлеглі тканини і забезпечує сталу повну ішемію протягом терміну експерименту [13]. У 2-й дослідній групі щурам моделювали гостру крововтрату в обсязі 20-22 \% об'єму циркулюючої крові шляхом пересікання стегнової вени. У 3-й дослідній групі ці ушкодження поєднували. У 4-й дослідній групі щурам із гострою крововтратою, ускладненою ішемією-реперфузією кінцівки, з метою корекції внутрішньочеревно вводили карбацетам (Інститут фрізико-органічної хімії і вуглехімії ім. Л. М. Литвиненка НАН України, Київ) в дозі 5 мг на 1 кг маси тварини [14].

За умов тіопентал-натрієвого наркозу щурів 1-ї, 2-ї і 3-ї дослідних груп виводили з експерименту через 1 й 2 год, а також через 1, 7 та 14 діб, тварин 4-ї дослідної групи - через 7 і 14 діб. У контрольній групі щурів лише вводили у наркоз, застосовуючи еквівалентну дозу тіопентал-натрію, накладали джгут без припинення кровотоку і в подальшому виводили з експерименту через 2 год.

Для досліджень брали селезінку, в гомогенаті якої визначали вміст ВГ за рівнем утворення тіонітрофенільного аніона в результаті взаємодії SH-груп глутатіону з 5,5-дитіобіс-2нітробензойною кислотою [15] та ГП активність (КФ 1.11.1.9) за швидкістю окиснення ВГ [16]. Вірогідність відмінностей між контрольною і дослідними групами оцінювали з використанням непараметричного критерію Манна Уїтні.

РЕЗУЛЬТАТИЙ ОБГОВОРЕННЯ. ДосліДЖеНня показали, що вміст у селезінці ВГ (табл. 1) через 1 і 2 год після моделювання ішемії-реперфуузії кінцівки, порівняно з контрольною групою, зростав, проте результат виявився статистично не вірогідним $(p>0,05)$. Починаючи із 7-ї доби реперфузійного періоду, показник суттєво знижувався (на 18,3 \%, р<0,05), проте до 14-ї доби нормалізувався, досягаючи рівня контрольної групи (р>0,05). За умов гострої крововтрати вміст у селезінці ВГ уже через 2 год експерименту істотно зменшувався порівняно 3 контрольною групою (на 19,0 \%, р<0,05), до 1-ї доби досягав мінімальної величини (на 50,7 \%, р<0,05) і в подальшому зростав, проте не досягав рівня контролю $(p<0,05)$. Після моделювання гострої крововтрати, ускладненої ішемією-реперфузією кінцівки, він знижувався ще більше. Результат, починаючи з 2 год експерименту, був статистично вірогідно меншим, ніж у контрольній групі, й досягав мінімального рівня через 1 добу (на $64,9 \%, p<0,05)$. 
Таблиця 1 - Вміст відновленого глутатіону в селезінці (ммоль· $\Gamma^{-1}$ ) після гострої крововтрати, ускладненої ішемією-реперфузією кінцівки ((Me (LQ; UQ) - медіана (нижній і верхній квартилі))

\begin{tabular}{|c|c|c|c|c|c|}
\hline \multirow{2}{*}{ Дослідна група } & \multicolumn{5}{|c|}{ Термін реперфузійного періоду } \\
\hline & 1 год & 2 год & 1-ша доба & 7-ма доба & 14-та доба \\
\hline \multicolumn{6}{|c|}{ Контроль=1,42 $(1,31 ; 1,61)(\mathrm{n}=6)$} \\
\hline 1-ша (ішемія-реперсрузія) & $\begin{array}{c}1,56 \\
(1,47 ; 1,59) \\
(n=6)\end{array}$ & $\begin{array}{c}1,73 \\
(1,52 ; 1,81) \\
(n=6)\end{array}$ & $\begin{array}{c}1,34 \\
(1,29 ; 1,38) \\
(n=6)\end{array}$ & $\begin{array}{c}1,16^{\star} \\
(1,08 ; 1,19) \\
(n=6)\end{array}$ & $\begin{array}{c}1,34 \\
(1,26 ; 1,51) \\
(n=6)\end{array}$ \\
\hline 2-га (гостра крововтрата) & $\begin{array}{c}1,27^{\star} \\
(1,18 ; 1,35) \\
(n=6)\end{array}$ & $\begin{array}{c}1,15^{\star} \\
(0,96 ; 1,22) \\
(n=6)\end{array}$ & $\begin{array}{c}0,70 * \\
(0,65 ; 0,85) \\
(n=6)\end{array}$ & $\begin{array}{c}0,95^{\star} \\
(0,90 ; 1,04) \\
(n=6)\end{array}$ & $\begin{array}{c}1,09^{*} \\
(0,90 ; 1,22) \\
(n=6)\end{array}$ \\
\hline $\begin{array}{l}\text { 3-тя (ішемія-реперфузія+ } \\
\text { гостра крововтрата }\end{array}$ & $\begin{array}{c}1,29 * \\
(1,17 ; 1,35) \\
(n=6)\end{array}$ & $\begin{array}{c}0,96^{\star} \\
(0,90 ; 1,08) \\
(n=6)\end{array}$ & $\begin{array}{c}0,47^{\star} \\
(0,37 ; 0,56) \\
(n=6)\end{array}$ & $\begin{array}{c}0,61^{\star} \\
(0,54 ; 0,65) \\
(n=6)\end{array}$ & $\begin{array}{c}0,78^{\star} \\
(0,75 ; 0,85) \\
(n=6)\end{array}$ \\
\hline $\mathrm{p}_{1-2}$ & $<0,05$ & $<0,05$ & $<0,05$ & $<0,05$ & $<0,05$ \\
\hline $\mathrm{p}_{1-3}$ & $<0,05$ & $<0,05$ & $<0,05$ & $<0,05$ & $<0,05$ \\
\hline $\mathrm{p}_{2-3}$ & $>0,05$ & $>0,05$ & $<0,05$ & $<0,05$ & $<0,05$ \\
\hline
\end{tabular}

Примітки. Тут і в таблиці 2:

1. * - відмінності стосовно контрольної групи статистично вірогідні $(p<0,05)$.

2. $\mathrm{p}_{1-2}$ - вірогідність відмінностей між 1-ю і 2-ю дослідними групами.

3. $\mathrm{p}_{1-3}$ - вірогідність відмінностей між 1-ю і 3-ю дослідними групами.

4. $\mathrm{p}_{2-3}$ - вірогідність відмінностей між 2-ю і 3-ю дослідними групами.

Порівняння дослідних груп між собою показало, що через 1 й 2 год експерименту показник виявився істотно нижчим у 2-й і 3-й дослідних групах, в яких моделювали гостру крововтрату та поєднували ії з ішемією-реперсузією кінцівки, порівняно 3 1-ю дослідною групою, в якій моделювали лише ішемію-реперфузію $\left(p_{1-2}<0,05\right.$, $\left.\mathrm{p}_{1-3}<0,05\right)$. Починаючи з 1-ї доби і до закінчення експерименту, вміст ВГ у селезінці ставав статистично вірогідно меншим зі зростанням тяжкості ураження $\left(\mathrm{p}_{1-2}<0,05, \mathrm{p}_{1-3}<0,05, \mathrm{p}_{2-3}<0,05\right)$.

У свою чергу, ГП активність за умов моделювання лише ішемії-реперфузії кінцівки через 2 год, 1 та 7 діб реперфузійного періоду компенсаторно підвищувалась (відповідно, на 19,9, 45,6 i 37,0 \%, p<0,05) (табл. 2). Через 14 діб показник повертався до рівня контрольної групи ( $p>0,05)$. Після моделювання гострої крововтрати ГП ак- тивність у селезінці, навпаки, знижувалась порівняно з контрольною групою, починаючи 32 год експерименту $(p<0,05)$. В цей термін показник досягав мінімуму і залишався на такому ж рівні до 14-ї доби експерименту. Ускладнення гострої крововтрати ішемією-реперфузією кінцівки теж супроводжувалося статистично значущим зменшенням ГП активності порівняно з контрольною групою, починаючи з 2 год експерименту (на $42,8 \%, p<0,05)$. Показник досягав мінімуму через 1 та 7 діб (відповідно, на 65,7 і 57,2 \%, p<0,05).

Порівняння дослідних груп між собою показало, що через 1 год ГП активність у селезінці виявилась істотно меншою у групах, в яких моделювали ішемію-реперфузію кінцівки та поєднували ії̈ 3 гострою крововтратою $\left(\mathrm{p}_{1-2}<0,05\right.$, $\left.\mathrm{p}_{2-3}<0,05\right)$. Через 2 год, 7 i 14 діб показник ставав істотно нижчим у групах, в яких моделювали

Таблиця 2 - Глутатіонпероксидазна активність у селезінці (ммоль:Хв-1.кг-1) після гострої крововтрати, ускладненої ішемією-реперфузією кінцівки ((Me (LQ; UQ) - медіана (нижній і верхній квартилі))

\begin{tabular}{|c|c|c|c|c|c|}
\hline \multirow{2}{*}{ Дослідна група } & \multicolumn{5}{|c|}{ Термін реперфузійного періоду } \\
\hline & 1 год & 2 год & 1-ша доба & 7-ма доба & 14-та доба \\
\hline \multicolumn{6}{|c|}{ Контроль $=0,47(0,45 ; 0,51)(n=6)$} \\
\hline 1-ша (ішемія-реперфуузія) & $\begin{array}{c}0,42 \\
(0,37 ; 0,46) \\
(n=6)\end{array}$ & $\begin{array}{c}0,56^{\star} \\
(0,53 ; 0,61) \\
(n=6)\end{array}$ & $\begin{array}{c}0,68^{\star} \\
(0,57 ; 0,89) \\
(n=6)\end{array}$ & $\begin{array}{c}0,64^{*} \\
(0,47 ; 0,75) \\
(n=6)\end{array}$ & $\begin{array}{c}0,53 \\
(0,44 ; 0,57) \\
(n=6)\end{array}$ \\
\hline 2-га (гостра крововтрата) & $\begin{array}{c}0,54 \\
(0,49 ; 0,62) \\
(n=6)\end{array}$ & $\begin{array}{c}0,33^{\star} \\
(0,29 ; 0,42) \\
(n=6)\end{array}$ & $\begin{array}{c}0,27^{*} \\
(0,20 ; 0,32) \\
(n=6)\end{array}$ & $\begin{array}{c}0,28^{*} \\
(0,24 ; 0,30) \\
(n=6)\end{array}$ & $\begin{array}{c}0,34^{*} \\
(0,25 ; 0,38) \\
(n=6)\end{array}$ \\
\hline $\begin{array}{l}\text { 3-тя (ішемія-реперфузія+ } \\
\text { крововтрата }\end{array}$ & $\begin{array}{c}0,41 \\
(0,37 ; 0,44) \\
(n=6)\end{array}$ & $\begin{array}{c}0,27^{\star} \\
(0,25 ; 0,33) \\
(n=6)\end{array}$ & $\begin{array}{c}0,16^{*} \\
(0,14 ; 0,18) \\
(n=6)\end{array}$ & $\begin{array}{c}0,20^{*} \\
(0,18 ; 0,24) \\
(n=6)\end{array}$ & $\begin{array}{c}0,26^{\star} \\
(0,19 ; 0,32) \\
(n=6)\end{array}$ \\
\hline $\mathrm{p}_{1-2}$ & $<0,05$ & $<0,05$ & $<0,05$ & $<0,05$ & $<0,05$ \\
\hline$p_{1-3}$ & $>0,05$ & $<0,05$ & $<0,05$ & $<0,05$ & $<0,05$ \\
\hline $\mathrm{p}_{2-3}$ & $<0,05$ & $>0,05$ & $<0,05$ & $>0,05$ & $>0,05$ \\
\hline
\end{tabular}


гостру крововтрату та ускладнювали ії ішемією-репердузією кінцівки $\left(\mathrm{p}_{1-2}<0,05, \mathrm{p}_{1-3}<0,05\right)$. Тільки через 1 добу експерименту ГП активність у селезінці зі зростанням тяжкості ураження ставала істотно меншою $\left(\mathrm{p}_{1-2}<0,05, \mathrm{p}_{1-3}<0,05\right.$, $\left.\mathrm{p}_{2-3}<0,05\right)$.

Застосування карбацетаму в щурів із гострою крововтратою, ускладненою ішемією-реперфрузією кінцівки, призвело до збільшення вмісту ВГ у селезінці (рис. 1) через 7 і 14 діб порівняно з тваринами без корекції, проте тільки через 7 діб результат був статистично вірогідним (на 60,6 \%, p<0,05). Через 14 діб показник у щурів з корекцією перебував на рівні тварин без корекції та не досягав рівня контрольної групи (p<0,05).

У свою чергу, ГП активність під впливом карбацетаму, порівняно з тваринами без корекції, теж зростала: через 7 діб - на 40,0 \% (p>0,05), через 14 діб - на 38,4 \%, що виявилося статистично значущим $(p<0,05)$ і не досягало рівня контрольної групи (р<0,05) (рис. 2).

Таким чином, у патогенезі ішемії-реперфузії кінцівки важливе значення мають зниження вмісту ВГ через 7 діб та компенсаторне зростання ГП активності через 1 і 7 діб реперфузійного періоду, які до 14-ї доби експерименту нормалізувалися. За цих умов, очевидно, має місце вплив ендотоксинів, які у реперфузійний період надходять у системний кровотік 3 ішемізованої кінцівки. Останні можуть зумовити метаболічний ацидоз, гіперкаліємію та міоглобінемію [17] 3 накопиченням супероксидного радикала в гомогенатах м'язів, внутрішніх органів і плазмі крові [18] і збільшенням утворення прозапальних цитокінів [19].
За умов гострої крововтрати порушення досліджуваних показників ГАПС зростають, починаючи з 2 год експерименту, з мінімумом через 1 добу та не досягають рівня контрольної групи до 14-ї доби. Виявлені порушення є загальною закономірністю реакції тканин організму на гіпоксію, зумовлену крововтратою [20]. Однак ще більші порушення виникали при поєднанні гострої крововтрати й ішемії-реперфрузії кінцівки з найбільшим виснаженням вмісту ВГ і ГП активності через 1 добу експерименту. Отже, має місце нашарування патогенних механізмів гострої крововтрати й ішемії-реперфузії кінцівки, що може негативно позначитися на адаптаційно-компенсаторних фрункціях селезінки. Останнє підтверджується дослідженнями інших авторів, які за цих умов відмічали суттєве зниження функціонального стану печінки [21], нирок [14] і легень [9]. Уведення карбацетаму тваринам із гострою крововтратою та ішемією-реперфузією кінцівки знижувало інтенсивність порушень вмісту ВГ і ГП активності у селезінці, що підтверджувало протекторний вплив препарату на антиоксидантну систему внутрішніх органів, який встановили інші автори $[9,14,21]$.

Таким чином, у механізмах гострої крововтрати, ускладненої ішемією-реперфузією кінцівки, провідну роль відіграє порушення ГАПС. За цих умов карбацетам захищає селезінку від виснаження вмісту ВГ і ГП активності, що ставить його в ряд перспективних засобів комплексної терапії порушень, зумовлених гострою крововтратою та ішемічно-реперфузійним синдромом.

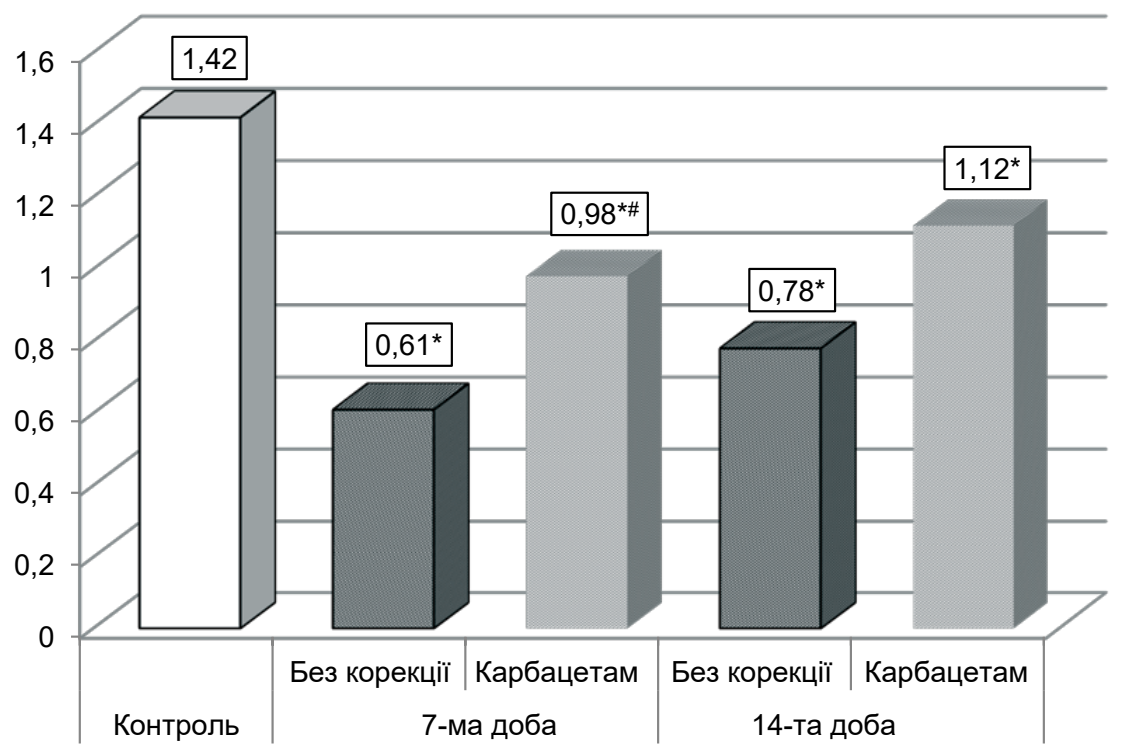

Рис. 1. Вплив карбацетаму на вміст відновленого глутатіону в селезінці (ммоль: $\Gamma^{-1}$ ) після гострої крововтрати, ускладненої ішемією-реперфузією кінцівки.

Примітка. Тут і на рисунку 2: * - відмінності стосовно контрольної групи щурів статистично вірогідні $(p<0,05)$; \# відмінності щодо групи тварин без корекції статистично вірогідні $(\mathrm{p}<0,05)$. 


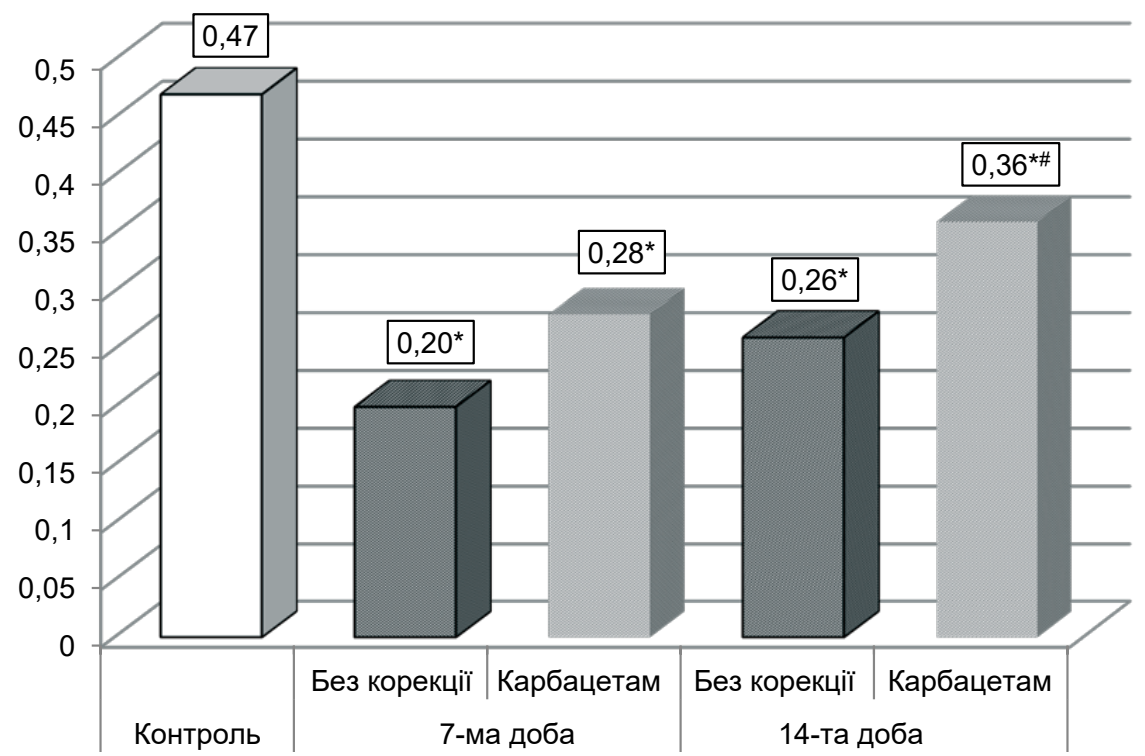

Рис. 2. Вплив карбацетаму на глутатіонпероксидазну активність у селезінці (ммоль·хв ${ }^{-1} \cdot \mathrm{K}^{-1}$ ) після гострої крововтрати, ускладненої ішемією-реперфузією кінцівки.

ВИСНОВКИ. 1. Моделювання гострої крововтрати, ускладненої ішемією-реперфузією кінцівки, зумовлює зниження вмісту відновленого глутатіону і глутатіонпероксидазної активності в селезінці з максимумом через 1 добу експерименту.

2. Карбацетам сприяє протекції порушень вмісту відновленого глутатіону в селезінці через
7 діб застосування, глутатіонпероксидазної активності-через 14 діб, що свідчить про перспективність препарату за умов гострої крововтрати й ішемічно-реперфузійного синдрому.

Перспективи подальших досліджень. У перспективі слід вивчити роль ішемії-реперфузії кінцівки в патогенезі впливу гострої крововтрати на морфологічну перебудову селезінки.

\section{СПИСОК ЛІТЕРАТУРИ}

1. Свободно-радикальные процессы в биосистемах:учеб. пособ./ Т. В. Попова, А. Н. Пашков, А. В. Семенихина, С. С. Попов. - Воронеж : Изд-во ИПК "Кириллица", 2008. - 192 с.

2. Бєленічев І. Ф. Антиоксидантна система захисту організму (огляд) [Електронний ресурс]/І. Ф. Бєленічев, Е. Л. Левицький, Ю. І. Губський // Сучасні проблеми токсикології. - 2002. - № 3. - Режим доступу http://www.medved.kiev.ua/arhiv_mg/st_2002/02_3_3. htm.

3. Ковальчук В. И. Корреция липидного состава мембран эритроцитов антиоксидантами у детей с острыми гнойными заболеваниями / В. И. Ковальчук, Б. И. Мацкевич // Система транспорта кислорода. 2004. - № 1. - С. 55-61.

4. Козлов Ю. П. Биооксиданты в регуляции метаболизма в норме и патологии / Ю. П. Козлов, В. Е. Каган. - Черноголовка : Буква, 2006. - 76 с.

5. Kalinina E. V. Role of glutathione, glutathione transferase, and glutaredoxin in regulation of redoxdependent processes / E. V. Kalinina, N. N. Chernov, M. D. Novichkova // Biochemistry. - 2014. - 79 (13). P. 1562-1583.

6. Ischemia/reperfusion injury alters sphingolipid metabolism in the gut/ R. S. Hoehn, A. P. Seitz, P. L. Jerni- gan [et al.] // Cell Physiol. Biochem. - 2016. - 39 (4). P. 1262-1270.

7. Point of injury tourniquet application during Operation Protective Edge-What do we learn? / A. Shlaifer, A. Yitzhak, E. N. Baruch [et al.] // J. Trauma Acute Care Surg. - 2017. - 83 (2). - P. 278-283.

8. Максимів Р. В. Динаміка балансу антиоксидантно-прооксидантних механізмів у внутрішніх органах під впливом артеріального джгута і реперфузії кінцівки / Р. В. Максимів, А. А. Гудима, В. М. Сидоренко // Шпитальна хірургія. Журн. імені Л. Я. Ковальчука. 2017. - № 1. - С. 37-44.

9. Порушення вмісту відновленого глутатіону в легенях щурів на тлі гострої крововтрати, ускладненої ішемією-реперфузією кінцівки, та їх корекція карбацетамом / О. В. Стахів, А. А. Гудима, І. В. Корда, Ю. В. Угляр // Мед. та клініч. хімія. - 2020. - 22, № 3 (85). - С. 74-80.

10. Лобов В. В. Гемопоэтическая фрункция селезенки в постгеморрагическом периоде / В. В. Лобов, Ю. В. Начаров, А. А. Зубахин // Вестн. НГУ. Серия "Биология, клиническая медицина". - 2006. - 4, вып. 2. - С. 78-83.

11. Морфо-фрункціональна організація селезінки лабораторних тварин (огляд літератури) / О. В. Аві- 
лова, О. О. Приходько, О. О. Трач [та ін.] // Світ медицини та біології. - 2017. - № 1 (59). - С. 175-179.

12. Яворська І. В. Динаміка активності процесів ліпідної пероксидації в селезінці під впливом гострої крововтрати, ускладненої ішемією-реперсузією кінцівки, та ї̈ корекція карбацетамом / І. В. Яворська, І. Я. Господарський // Здобутки клініч. і експерим. медицини. - 2020. - № 4. - С. 178-185.

13. Tourniquets and occlusion: the pressure of design / P. L. Wall, D. C. Duevel, M. B. Hassan [et al.] // Mil. Med. - 2013. - 178 (5). - P. 578-587.

14. Шацький В. В. Динаміка антиоксидантно-прооксидантного балансу кіркового і мозкового шарів нирки після гострої крововтрати, ускладненої ішемією-реперфузією кінцівки, та його корекція карбацетамом / В. В. Шацький, А. А. Гудима, Л. Я. Федонюк // Здобутки клініч. і експерим. медицини. -2019. - № 4. C. 144-153.

15. Ellman G. L. Tissue sulfhydryl groups / G. L. Ellman // Arch. Biochem. Biophys. - 1959. - 82, No. 1. - P. 70-77.

16. Куликова Г. О. Глутатионпероксидазная и глутатионредуктазная активность печени крыс после введения селенита натрия / Г. О. Куликова,
И. М. Штурман // Укр. біохім. журн. - 1976. - 48, № 2. - C. 223-227.

17. Morsey H. Patients with critical ischemia of the lower limb are at risk of developing kidney dysfunction / H. Morsey, M. Aslam, N. Standfield // Am. J. Surg. 2003. - 185 (4). - P. 360-363.

18. Concentration decrease of nitric oxide in the postischemic muscle is not only caused by the generation of O2- / F. Stoffels, F. Lohöfener, M. Beisenhirtz [et al.] // Microsurgery. - 2007. - 27, No. 6. - P. 565-568.

19. Van der Spuy L. A. Complications of the arterial tourniquet / L. A. Van der Spuy // S. Afr. J. Anaesth. Analges. - 2012. - 18 (1). - P. 14-18. DOI: https://doi.org/ 10.1080/22201173.2012.10872818.

20. Antioxidant-prooxidant balance in abdominal injury, hypovolemic shock and reperfusion syndrome of the limbs in experiment / V. O. Krylyuk, V. K. Grodetskyi, I. V. Kuzminsky [et al.] // Int. Sci. Periodical J. "The Unity of Science". - 2019. - No. 1. - P. 149-153.

21. Горбань І. І. Вплив гострої крововтрати, ускладненої ішемією-реперфузією кінцівки, на антиоксидантно-прооксидантний баланс печінки та його корекція карбацетамом / І. І. Горбань // Здобутки клініч. і експерим. медицини. - 2020. - № 2. - С. 93-100.

\section{REFERENCES}

1. Popova, T.V., Pashkov, A.N., Semenikhina, A.V., \& Popov, S.S. (2008). Svobodno-radikalnyye protsessy v biosistemakh: ucheb. posobiye [Free radical processes in biosystems: textbook]. Voronezh: Izd-vo IPK "Kirillitsa" [in Russian].

2. Bielenichev, I.F., Levytskyi, E.L., \& Hubskyi, Yu.I. (2002). Antyoksydantna systema zakhystu orhanizmu (ohliad). Suchasni problemy toksykolohiyi - Modern Problems of Toxicology, 3. Retrieved from: http://www. medved.kiev.ua/arhiv_mg/st_2002/02_3_3.htm [in Ukrainian].

3. Kovalchuk, V.I., \& Matskevich, B.I. (2004). Korretsiya lipidnogo sostava membran eritrotsitov antioksidantami u detey s ostrymi gnoynymi zabolevaniyami [Correction of the lipid composition of erythrocyte membranes with antioxidants in children with acute purulent diseases]. Sistema transporta kisloroda-Oxygen Transport System, 1, 55-61 [in Russian].

4. Kozlov, Yu.P., \& Kagan, V.Ye. (2006). Biooksidanty $v$ regulyatsii metabolizma $v$ norme i patologi [Biooxidants in the regulation of metabolism in health and disease]. Chernogolovka: Bukva [in Russian].

5. Kalinina, E.V., Chernov, N.N., \& Novichkova, M.D. (2014). Role of glutathione, glutathione transferase, and glutaredoxin in regulation of redox-dependent processes. Biochemistry, 79 (13), 1562-1583.

6. Hoehn, R.S., Seitz, A.P., Jernigan, P.L., Gulbins, E., \& Edwards, M.J. (2016). Ischemia/reperfusion injury alters sphingolipid metabolism in the gut. Cell Physiol. Biochem., 39 (4), 1262-1270. DOI: 10.1159/000447831.

7. Shlaifer, A., Yitzhak, A., Baruch, E.N., Shina, A., Satanovsky, A., Shovali, A., ..., \& Glassberg, E. (2017). Point of injury tourniquet application during Operation Protective Edge-What do we learn? J. Trauma Acute
Care Surg., 83 (2), 278-283. DOI: 10.1097/ TA.0000000000001403.

8. Maksymiv, R.V., Hudyma, A.A., \& Sydorenko, V.M. (2017). Dynamika balansu antyoksydantno-prooksydantnykh mekhanizmiv u vnutrishnikh orhanakh pid vplyvom arterialnoho dzhhuta i reperfuzii kintsivky [Dynamic of balance of antioxidant-prooxidant mechanism in internal organs under the influence of blood harnesses and limb reperfusion]. Shpytalna khirurhiia. Zhurnal imeni L. Ya. Kovalchuka - Hospital Surgery. Journal named by L. Ya. Kovalchuk, 1, 37-44. DOI: 10.11603/24144533.2017.1.7637 [in Ukrainian].

9. Stakhiv, O.V., Hudyma, A.A., Korda, I.V., \& Uglyar, Yu.V. (2020). Porushennia vmistu vidnovlenoho hlutationu v leheniakh shchuriv na tli hostroi krovovtraty, uskladnenoi ishemiieiu-reperfuziieiu kintsivky, ta yikh korektsiya karbatsetamom [Disturbance of the content of restorated glutation in the lungs of rats on the background of acute blood loss complicated by ischemia-reperfusion of the limbs and their correction with carbacetam]. Medychna ta klinichna khimiia - Medical and Clinical Chemistry, 22, 3, 74-80. DOI: https://doi.org/10.11603/ mcch.2410-681X.2020.v.i3.11537 [in Ukrainian].

10. Lobov, V.V., Nacharov, Yu.V., \& Zubakhin, A.A. (2006). Gemopoeticheskaya funktsiya selezenki v postgemorragicheskom periode [Hematopoietic function of the spleen in the posthemorrhagic period]. Vestnik NGU. Ser.: biologiya, klinicheskaya meditsina-Bulletin of NSU. Ser.: Biology, Clinical Medicine, 4, 2, 78-83 [in Russian].

11. Avilova, O.V., Prykhodko, O.O., Trach, O.O, Yarmolenko, O.S., \& Bumeyster, L.V. (2017). Morfofunktsionalna orhanizatsiia selezinky laboratornykh tvaryn (ohliad literatury) [Morpho-functional organization of the spleen of the laboratory animals]. Svit medytsyny ta bi- 
olohii - World of Medicine and Biology, 1 (59), 175-179 [in Ukrainian].

12. Yavorska, I.V., \& Hospodarsky, I.Ya. (2020). Dynamika aktyvnosti protsesiv lipidnoi peroksydatsii $v$ selezintsi pid vplyvom hostroi krovovtraty, uskladnenoi ishemiieiu-reperfuziieiu kintsivky, ta yii korektsiia karbatsetamom [Dynamics of activity of lipid peroxidation processes in the spleen under the influence of acute blood loss, complicated by ischemiareperfusion of the limb and its correction with carbacetam]. Zdobutky klinichnoi i eksperymentalnoi medytsyny - Achievements of Clinical and Experimental Medicine, 4, 178-185. DOI: 10.11603/ 1811-2471.2020.v.i4.11771 [in Ukrainian].

13. Wall, P.L., Duevel, D.C., Hassan, M.B., Welander, J.D., Sahr, S.M., \& Buising, C.M. (2013). Tourniquets and occlusion: the pressure of design. Mil. Med., 178 (5), 578-587. DOI: 10.7205/MILMED-D-12-00490.

14. Shatsky, V.V., Gudyma, A.A., \& Fedoniuk, L.Ya. (2019). Dynamika antyoksydantno-prooksydantnoho balansu kirkovoho i mozkovoho shariv nyrky pislia hostroi krovovtraty, uskladnenoi ishemiieiu-reperfuziieiu kintsivky, ta yoho korektsiia karbatsetamom [Dynamics of antioxidant-prooxidant balance of renal cortex and medulla after acute blood loss complicated by ischemia-reperfusion of the extremity, and its correction with carbacetam] Zdobutky klinichnoi i eksperymentalnoi medytsyny Achievements of Clinical and Experimental Medicine, 4 144-153. DOI: 10.11603/1811-2471.2019.v.i4.10815 [in Ukrainian].

15. Ellman, G.L. (1959). Tissue sulfhydryl groups. Arch. Biochem. Biophys., 82, 1, 70-77. DOI: 10.1016/ 0003-9861(59)90090-6.

16. Kulikova, G.O., \& Shturman, I.M. (1976). Glutationperoksidaznaya i glutationreduktaznaya aktivnost pecheni krys posle vvedeniya selenita natriya [Glutathione peroxidase and glutathione reductase activity of rat liver after administration of sodium selenite]. Ukrainskyi biokhimichnyi zhurnal - Ukrainian Biochemical Journal, 48, 2, 223-227 [in Ukrainian].

17. Morsey, H., Aslam, M., \& Standfield, N. (2003). Patients with critical ischemia of the lower limb are at risk of developing kidney dysfunction. Am. J. Surg., 185 (4), 360-363. DOI: 10.1016/s0002-9610(02)01406-x.

18. Stoffels, F., Lohöfener, F., Beisenhirtz, M., Lisdat, F., \& Büttemeyer, R. (2007). Concentration decrease of nitric oxide in the postischemic muscle is not only caused by the generation of O2-. Microsurgery, 27 (6), 565-568. DOI: 10.1002/micr.20403.

19. Van der Spuy, L.A. (2012). Complications of the arterial tourniquet. S. Afr. J. Anaesth. Analges., 18 (1), 14-18. DOI: https://doi.org/10.1080/22201173.2012. 10872818.

20. Krylyuk, V.O., Grodetskyi, V.K., Kuzminsky, I.V., Tsimbalyuk, G.Yu., Fedoseeva, O.V., Gariyan, S.V., ..., \& Sokolnyk, S.O. (2019). Antioxidant-prooxidant balance in abdominal injury, hypovolemic shock and reperfusion syndrome of the limbs in experiment. Int. Sci. Periodical J. "The Unity of Science", 1, 149-153.

21. Horban, I.I. (2020). Vplyv hostroi krovovtraty, uskladnenoi ishemiieiu-reperfuziieiu kintsivky, na antyoksydantno-prooksydantnyi balans pechinky ta yoho korektsiia karbatsetamom [The effect of acute blood loss complicated by limb ischemia-reperfusion on the antioxidant-prooxidant balance of the liver and its correction by carbacetam]. Zdobutky klinichnoi i eksperymentalnoi medytsyny - Achievements of Clinical and Experimental Medicine, 2, 93-100. DOI: https://doi.org/10.11603/18112471.2020.v.i2.11320 [in Ukrainian].

И. В. Яворская

\section{ВЛИЯНИЕ ОСТРОЙ КРОВОПОТЕРИ, ОСЛОЖНЕННОЙ ИШЕМИЕЙ- РЕПЕРФУЗИЕЙ КОНЕЧНОСТИ, НА ДИНАМИКУ ПОКАЗАТЕЛЕЙ ГЛУТАТИОНОВОЙ АНТИПЕРОКСИДАЗНОЙ СИСТЕМЫ В СЕЛЕЗЕНКЕ И ЕГО КОРРЕКЦИЯ КАРБАЦЕТАМОМ}

\section{Резюме}

Вступление. Нарушение глутатионовой антипероксидазной системы является одним из ключевых механизмов острой кровопотери и ишемически-реперфузионного синдрома. В адаптационно-компенсаторных процессах при кровопотери важную роль играет селезенка. Однако состояние глутатионовой антипероксидазной системы в селезенке изучено недостаточно. Нет данных об эфрфективности в этих условиях карбацетама, который проявил выраженное протекторное влияние на энзимное звено антиоксидантной защиты селезенки.

Цель исследования - выяснить динамику показателей глутатионовой антипероксидазной системы в селезенке в условиях острой кровопотери, осложненной ишемией-реперфузией конечности, и оценить эфрфективность коррекции выявленных нарушений карбацетамом.

Методы исследования. В экспериментах использовано 108 нелинейных крыс-самцов массой 200-220 2. Все эксперименты выполнено под тиопентал-натриевым наркозом. У животных моделировали ишемию-реперфузию конечности, острую кровопотерю и сочетали эти повреждения. В отдельной группе проводили коррекцию выявленных нарушений карбацетамом. Через 1 и 2 ч, а также через 1, 7 и 14 суток 
в селезенке подопытных животных определяли содержание восстановленного глутатиона и глутатионпероксидазную активность.

Результаты и обсуждение. Моделирование острой кровопотери, осложненной ишемией-реперфузией конечности, в селезенке способствует наибольшему истощению содержания восстановленного глутатиона и глутатионпероксидазной активности, начиная со 2 ч эксперимента. Через 1 сутки величина исследуемых показателей достигала минимального уровня и была статистически достоверно меньше, чем в условиях моделирования только острой кровопотери. Применение карбацетама имело протекторное влияние на содержание в селезенке восстановленного глутатиона (после 7 суток использования) и глутатионпероксидазную активность (через 14 суток), что ставит карбацетам в ряд перспективных средств комплексной терапии нарушений, обусловленных острой кровопотерей и ищемически-реперфузионным синдромом.

Выводы. Моделирование острой кровопотери, осложненной ишемией-реперфузией конечности, приводит к снижению содержания восстановленного глутатиона и глутатионпероксидазной активности в селезенке с максимумом через 1 сутки эксперимента. Применение карбацетама способствует протекции нарушений содержания восстановленного глутатиона в селезенке через 7 суток использования, глутатионпероксидазной активности - через 14 суток.

КЛЮЧЕВЫЕ СЛОВА: острая кровопотеря; ишемия-реперфузия конечности; селезенка; восстановленный глутатион; глутатионпероксидаза; карбацетам.

I. V. Yavorska

I. HORBACHEVSKY TERNOPIL NATIONAL MEDICAL UNIVERSITY

\section{INFLUENCE OF ACUTE BLOOD LOSS COMPLICATED BY LIMB ISCHEMIA- REPERFUSION ON THE DYNAMICS OF GLUTATION ANTIPEROXIDASE INDICATORS IN THE SPLEEN AND ITS CORRECTION WITH CARBACETAM}

\section{Summary}

Introduction. Disruption of the glutathione antiperoxidase system is one of the key mechanisms of acute blood loss and ischemic-reperfusion syndrome. The spleen plays an important role in adaptive-compensatory processes in the conditions of blood loss. However, the state of the glutathione antiperoxidase system in the spleen has not been studied enough. There are no data on the effectiveness under these conditions of carbacetam, which found a pronounced protective effect on the enzyme link of antioxidant protection of the spleen.

The aim of the study - to determine the dynamics of the glutathione antiperoxidase system of the spleen in conditions of acute blood loss complicated by ischemia-reperfusion of the limb and to evaluate the effectiveness of correction of the identified disorders by carbacetam.

Research Methods. 108 nonlinear male rats weighing 200-220 g were used in the experiments. All experiments were performed under thiopental-sodium anesthesia. In animals, limb ischemia-reperfusion and acute blood loss were simulated and these lesions were combined. In a separate group, the detected disorders were corrected with carbacetam. After 1 and 2 hours, as well as after 1, 7 and 14 days in the spleen of experimental animals was determined the content of reduced glutathione and the activity of glutathione peroxidase.

Results and Discussion. Modeling of acute blood loss, complicated by ischemia-reperfusion of the limb, in the spleen contributes to the greatest depletion of reduced glutathione and the activity of glutathione peroxidase, starting with $2 \mathrm{~h}$ of the experiment. After 1 day, the value of the studied indicators reached a minimum level and was statistically significantly less than in the conditions of modeling only acute blood loss. The use of carbacetam had a protective effect on the content of reduced glutathione in the spleen after 7 days of use, the activity of glutathione peroxidase - after 14 days, which puts carbacetam in a number of promising means of complex therapy of disorders caused by acute blood loss and ischemic-reperfusion syndrome.

Conclusions. Simulation of acute blood loss complicated by ischemia-reperfusion of the limb leads to a decrease in the content of reduced glutathione and glutathione peroxidase activity in the spleen with a maximum after 1 day of the experiment. The use of carbacetam promotes the protection of disorders of the content of reduced glutathione in the spleen after 7 days of use, glutathione peroxidase activity - after 14 days.

KEY WORDS: acute blood loss; ischemia-limb reperfusion; spleen; reduced glutathione; glutathione peroxidase; carbacetam.

Адреса для листування: І. В. Яворська, Тернопільський національний медичний університет імені І. Я. Горбачевського мОз України, майдан Волі, 1, Тернопіль, 46001, Україна, e-mail: iavorska@tdmu.edu.ua. 